\title{
Affinity Versus Label-Free Isolation of Circulating Tumor Cells: Who Wins?
}

Vasudha Murlidhar, Lianette Rivera-Báez, and Sunitha Nagrath*

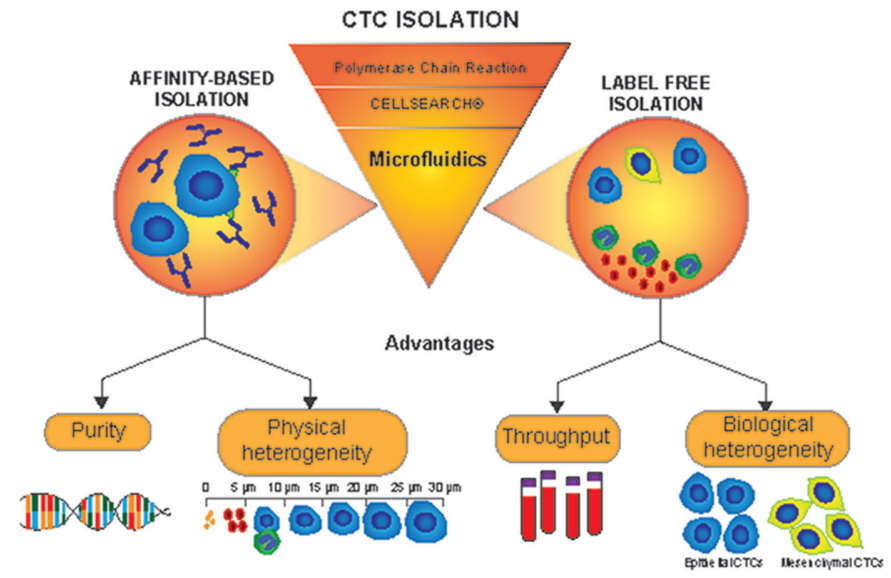

\section{From the Contents}

1. Introduction

2. Affinity-Based Isolation of CTCs

3. Label-Free Isolation of CTCS

4. The Future

5. Conclusion: Who Wins?....
.4451

.4452 .4456

.4459

.4460
The study of circulating tumor cells (CTCS) has been made possible by many technological advances in their isolation. Their isolation has seen many fronts, but each technology brings forth a new set of challenges to overcome. Microfluidics has been a key player in the capture of CTCs and their downstream analysis, with the aim of shedding light into their clinical application in cancer and metastasis. Researchers have taken diverging paths to isolate such cells from blood, ranging from affinity-based isolation targeting surface antigens expressed on CTCs, to label-free isolation taking advantage of the size differences between CTCs and other blood cells. For both major groups, many microfluidic technologies have reported high sensitivity and specificity for capturing CTCs. However, the question remains as to the superiority among these two isolation techniques, specifically to identify different CTC populations. This review highlights the key aspects of affinity and label-free microfluidic CTC technologies, and discusses which of these two would be the highest benefactor for the study of CTCs. 
www.MaterialsViews.com

\section{Introduction}

\subsection{Circulating Tumor Cells}

Emerging evidence has pointed to the importance of circulating tumor cells (CTCs) in the spread of cancers. ${ }^{[1]}$ CTCs, suspected of being precursors of metastasis ${ }^{[2]}$ have been in the spotlight as a liquid biopsy ${ }^{[3-6]}$ and are being investigated as surrogate biomarkers for clinical trials. ${ }^{[7-9]}$ These are cells shed by a primary tumor into the blood circulation, and can potentially form secondary tumors en route. ${ }^{[10]}$ Being intermediaries between the primary and metastatic tumors, they offer insights into both; additionally they can reveal key aspects of the metastatic cascade. Indeed, there have been studies showing that CTCs have distinct identities, consisting of a heterogeneous mix of populations similar to both the primary tumor and the metastatic tumor. ${ }^{[11-14]}$ CTCs can be detected from the peripheral blood of patients and hold the promise of being a real time biomarker for cancer detection and management. ${ }^{[15]}$ The utility of CTCs as a predictive and prognostic marker has been explored in various cancers like breast cancer, prostate cancer, liver cancer, and colorectal cancer. ${ }^{[16-19]}$ For example, in patients with metastatic breast cancer, the number of CTCs before and during treatment is an independent predictor of progression free and overall survival. ${ }^{[18,20]}$ Nagrath et al. surveyed patients from different cancers in advanced stages over their treatment course and showed that changes in CTC numbers could predict changes in the tumor burden. ${ }^{[21]}$ Elevated CTC numbers during treatment have also been shown to be associated with disease progression. ${ }^{[20,22]}$ Furthermore, it is possible to monitor treatment-resistant mutations and telomerase activity in CTCs, thereby demonstrating their clinical utility in therapeutic monitoring. ${ }^{[23,24]}$

The current gold standard for CTC isolation is the CellSearch (Veridex, USA) system, which is the only FDA approved system for CTC detection. ${ }^{[19]}$ This test separates epithelial cells using magnetic beads functionalized with antibodies against the epithelial cell adhesion molecule (EpCAM). ${ }^{[25]}$ Using the CellSearch system it has been shown that CTCs have prognostic utility in breast, prostate, and colon cancers. ${ }^{[19]}$ However, there is considerable cell loss $(\approx 20 \%-40 \%)$ caused by the inability of the platform to detect cancer cells with a reduced EpCAM expression, such as those that have gone through or are in the process of going through epithelial to mesenchymal transition (EMT). ${ }^{[26,27]}$ Currently, CTC studies are geared toward finding genetic signatures that could guide treatment decisions. ${ }^{[28]}$

The major challenge toward accomplishing more with these entities lies in their rarity; CTCs are detected at a frequency of tens among billions of blood cells. ${ }^{[29,30]}$ The vast majority of the background cells (blood cells) contribute to not only challenges in enriching for the target cells (CTCs), but purity issues during downstream molecular analyses. ${ }^{[1]}$ Attempts at increasing CTC concentrations by expanding them after isolation are hardened by viability issues. ${ }^{[30]}$ Hence, the key aspects of any CTC isolation technology should be a high recovery rate without compromising on purity and viability. ${ }^{[30]}$ A plethora of microfluidic technologies have risen to these challenges with promising results. With their help, scientists are now analyzing complex fluids such as blood in vitro, as a means to investigating noninvasive alternatives for cancer detection, patient prognosis and therapeutic monitoring. ${ }^{[15]}$

\subsection{The Use of Micro and Nanofluidics for Studying CTCS}

Microfluidic devices have had a major impact on the field of CTC research. ${ }^{[31]}$ Such efforts have been facilitated by the automation of labor-intensive experimental processes involved in isolating and characterizing CTCs. As a consequence, the microfluidic field has been gaining pace especially in the handling of rare cells. ${ }^{[30,32]}$ Different materials ranging from traditional silicon and glass to elastomers have been used for making these devices. The use of polydimethylsiloxane, an elastomer, has made rapid prototyping an easy and preferred method, leading to widespread use of microfluidic technologies for investigating CTCs. ${ }^{[29,33]}$ Their smaller dimensions allow precise manipulation of fluid flow in the devices, translating to better control over the cells. The smaller volumes also demand lesser reagents. ${ }^{[33]}$ Microfluidics for CTC isolation gained popularity with the reporting of the CTC-chip. ${ }^{[21]}$ Over the years, a large number of similar and innovative microfluidic platforms have come up, each exploiting specific properties of CTCs to separate them from blood cells. The different properties may be biological such as target antigens, or physical such as size, density, and deformity. ${ }^{[29,34]}$ This review compares the two most widelyused methodologies, namely affinity-based (biological) and size-based (physical) techniques of CTC isolation.

\subsection{Methods of CTC Isolation in Microfluidic Devices}

Microfluidic technologies are mainly categorized by their exploitation of CTCs' distinctive (i) biochemical properties or (ii) biophysical properties. The former is based on the expression of cell surface markers, while the latter includes size, deformability, density, and electric charge. ${ }^{[35]}$ For either of these strategies, it is imperative that developing an optimal CTC isolation method meet the following criteria: (i) high

\footnotetext{
V. Murlidhar, L. Rivera-Báez, Dr. S. Nagrath

Department of Chemical Engineering University of Michigan

3074 H.H. Dow, 2300 Hayward Street

Ann Arbor, MI 48109, USA

E-mail: snagrath@umich.edu

V. Murlidhar, L. Rivera-Báez, Dr. S. Nagrath

Biointerfaces Institute (BI)

University of Michigan

North Campus Research Complex

2800 Plymouth Road, Ann Arbor, MI 48109, USA

V. Murlidhar, L. Rivera-Báez, Dr. S. Nagrath

Translational Oncology Program (TOP)

University of Michigan

Ann Arbor, MI 48109, USA
}

DOI: $10.1002 / \mathrm{smll} .201601394$ 
recovery, (ii) high purity of CTCs by removal of contaminating blood cells, and (iii) high system throughput to ensure handling of large sample volumes as expected for clinical settings. ${ }^{[30]}$ Capture or retrieval of CTCs is followed by identification by immunocytochemical staining demonstrating positive signals for Cytokeratin(s) and the nuclear stain DAPI (4',6-diamidino-2-phenylindole), with the absence of the leukocyte marker CD45. ${ }^{[21]}$ Although there are multiple methods in each category of isolation, in this review we will focus on two of the most prevalent methods for CTC isolation- affinity, and size based or label-free isolation (Figure 1). We will highlight new progress and emerging technologies for each isolation method. Furthermore, we will elucidate the advantages and disadvantages based on their downstream applications for studying subpopulations and heterogeneity, genomic characterization, cell expansion, in vivo studies, and single cell analysis of CTCs. In this review, we will focus on highlighting the latest microfluidic technologies that have been characterized and proven to work with clinical samples (Table 1).

\section{Affinity-Based Isolation of CTCs}

\subsection{How It Works}

Affinity-based isolation, the main principle of technologies such as CellSearch and the CTC-chip, ${ }^{[21]}$ make use of the affinity of an antigen to its corresponding antibody. Antigens or surface markers present on the membrane of CTCs are targeted by specific antibodies that can be immobilized onto a solid surface. ${ }^{[36]}$ The antigens (and hence the cell) can grab on to the target antibodies under ideal conditions of affinity-binding. The bound cells can then be separated and/or identified for further assays, depending on their method of capture. The commonly used antigen for CTC capture is EpCAM, and is considered to be expressed by epithelial cancers. ${ }^{[15]}$ While recent findings have brought into question the utility of EpCAM in identifying the aggressors, ${ }^{[37]}$ it still remains the most widely adopted choice of capture antibodies. Combinations of antibodies are also being employed to widen the capture net. ${ }^{[38]}$

\subsection{Biomarker-Dependent Technologies for the Isolation of CTCs}

The first immuno-capture microfluidic technology for CTCs, the CTC-chip ${ }^{[21]}$ consists of a series of $100 \mu \mathrm{m}$ tall microposts coated with antibodies against EpCAM, which can interrogate whole blood for capturing CTCs expressing the antigen. The novelty of this technology lay in its ability to capture CTCs from whole blood with high sensitivity and viability. ${ }^{[21]}$ Following this, a number of technologies with varying degrees of sensitivity and purity were developed. The high-throughput microsampling unit, ${ }^{[39]}$ cell enrichment and extraction (CEE) channel, ${ }^{[40]}$ Herringbone chip or HB-chip, ${ }^{[33]}$ the graphene oxide chip, ${ }^{[41]}$ all performing EpCAM-based CTC capture, improved upon the above parameters (Figure 2). The NanoVelcro CTC chip, another recently developed immunocapture device, makes use of nanosized structures coated with

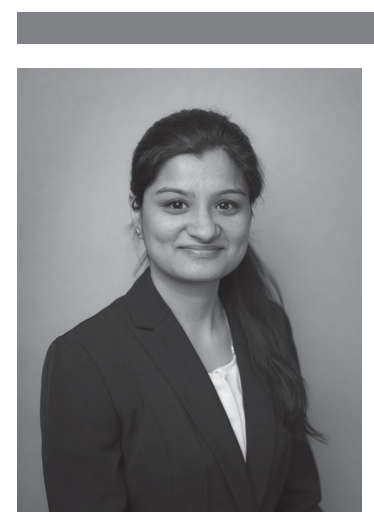

Vasudha Murlidhar completed her Bachelor of Technology (B.Tech.) in Chemical Engineering at National Institute of Technology, Tiruchirappalli, India, and her Master of Science in Engineering (Chemical Engineering) at University of Michigan, Ann Arbor. She is currently pursuing her Ph.D. in Chemical Engineering at University of Michigan, Ann Arbor, where she works in Dr. Sunitha Nagrath's lab on microfluidic isolation of circulating tumor cells and biological characterization of these cells.

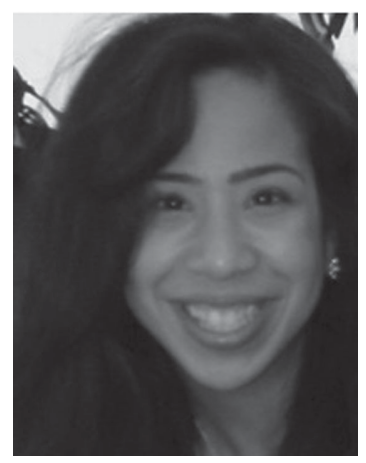

Lianette Rivera-Báez graduated from the University of Puerto Rico, Mayagüez with a Bachelor's degree in Industrial Biotechnology. She received her Master's degree in Chemical Engineering at the University of Michigan, Ann Arbor in 2014 She is currently pursuing her Ph.D. degree in Chemical Engineering in Prof. Sunitha Nagrath's lab. As an NSF-GFRP fellow, her research focuses on the development of label-free microfluidic technologies that target the enrichment, expansion, and characterization of circulating tumor cells.

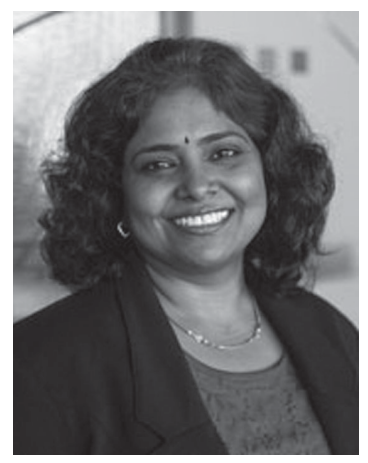

Sunitha Nagrath did her Bachelor's in Chemical Engineering from Sri Venkateswara University College of Engineering, Tirupathi, India. She received her Ph.D. in 2004 from Rensselaer Polytechnic Institute, Troy, NY in Mechanical Engineering. She did her postdoctoral work (2004-2008) at Harvard Medical/Massachusetts General Hospital, Boston. Dr. Nagrath is the leading scientist who designed the "CTC-Chip" for sensitive isolation of circulating tumor cells (CTCs) from the blood of cancer patients. She joined University of Michigan in 2010, where she established her laboratory focused on engineering innovative microfluidic devices and nanomaterials for implementing liquid biopsy, through isolation, characterization and study of circulating cells and exosomes in peripheral blood of cancer patients.

EpCAM for CTC capture. ${ }^{[42,43]}$ Other nanomaterial-based devices for CTC interrogation include the incorporation of carbon nanotubes, the porous nature of which provides a high surface area for cell interaction, ${ }^{[44,45]}$ and the use of $\mathrm{TiO}_{2}$ nanofibres produced by electrospinning techniques for anti-EpCAM capture of CTCs. ${ }^{[46]}$ The GEDI chip developed in 2010 ${ }^{[47]}$ has a similar approach and enabled CTC isolation with an antibody against prostate specific membrane antigen (PSMA). They showed an improved purity over the CTC-chip and also opened the arena for achieving CTC capture with antibodies other than EpCAM. Different antibodies or antibody cocktails have since been explored to capture different populations that may have been otherwise missed. Galletti et al. demonstrated the use of anti-Her2 for studying CTCs 


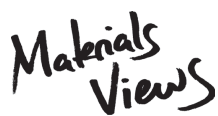

www.MaterialsViews.com

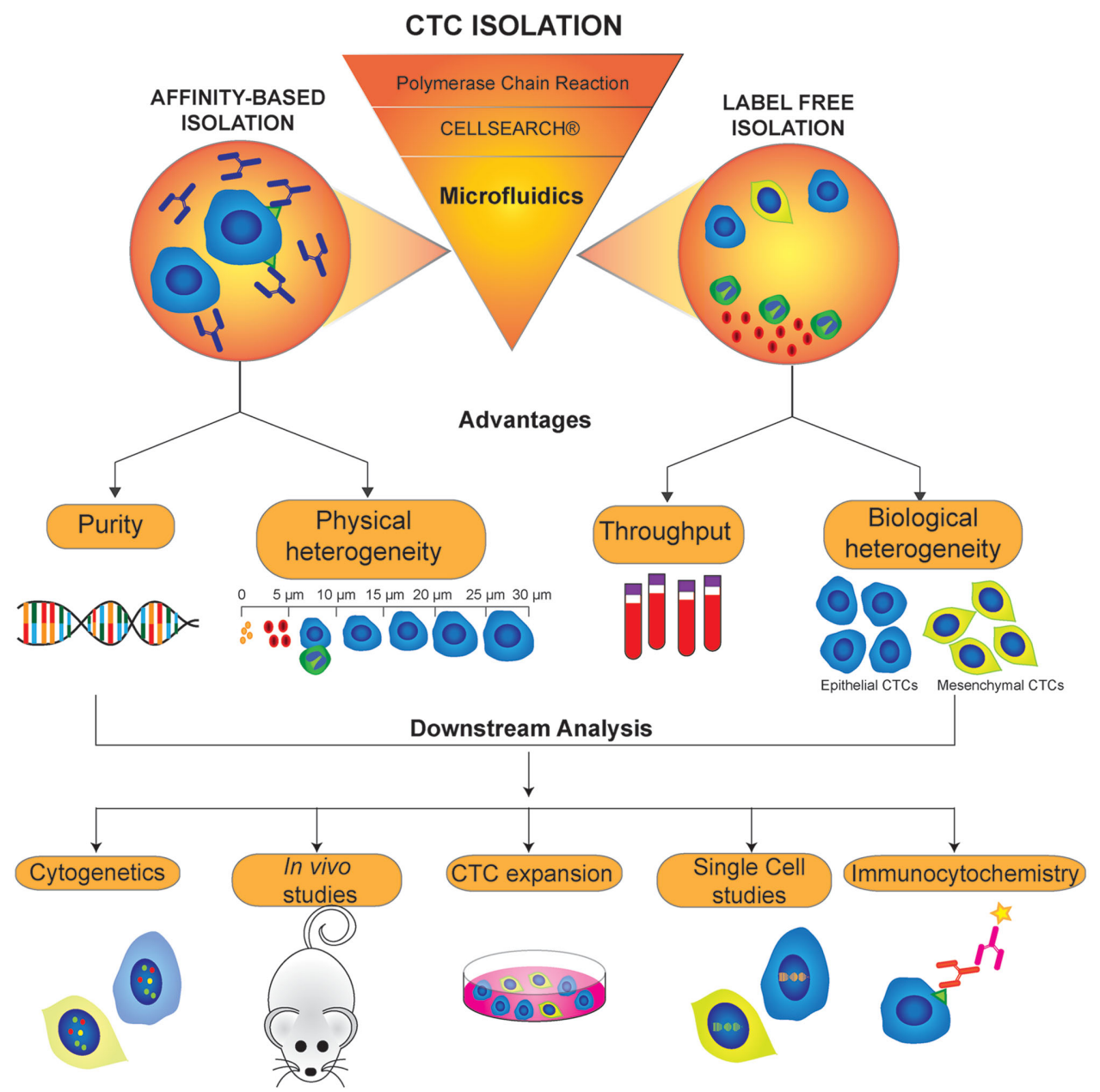

Figure 1. Isolation of circulating tumor cells (CTCS) is most popularly done by two strategies: affinity-based and label-free methods. Affinity-based techniques employ cell surface markers to capture CTCs, while label-free techniques exploit size differences between CTCs and blood cells. Both methods have their respective advantages and disadvantages, among them are high purity and the ability to capture physically/morphologically heterogeneous populations of CTCs by affinity-based methods, and high-throughput and the ability to capture biologically heterogeneous populations of CTCs by label-free methods. Microfluidic CTC isolation can also be used for a number of downstream applications for characterizing the CTCS.

from breast and gastric cancer. ${ }^{[48]} \mathrm{Yu}$ et al. used a mixture of EpCAM, EGFR, and Her2 to capture CTCs from breast cancer. ${ }^{[12]}$ Pecot et al. used an interesting approach wherein the cells are tagged with a cocktail of antibodies, followed by capture by functionalized microchannels. ${ }^{[38,40]}$ Aptamers, which can be synthesized to specifically recognize target molecules on the surface of cells, have also been incorporated for CTC capture. ${ }^{[49]}$ An example of a microfluidic aptamer-based affinity capture device was demonstrated by Sheng et al. for capture of colorectal CTCs from whole blood. ${ }^{[49]}$

Immuno-magnetic capture is also a popular method of affinity isolation wherein magnetic beads coated with antibodies are made to bind to cells in order to separate CTCs from while leukocytes (WBCs). ${ }^{[1]}$ MACS (magnetic activated cell sorter) is one such technology, that operates by separating cells bound to magnetic beads through a target antibody followed by purification under a magnetic field. ${ }^{[50]}$ Magnetic nanoparticles are also used to label cancer cells through anti-EpCAM to separate them from blood cells with high efficiency at a high flow rate of $10 \mathrm{~mL} \mathrm{~h}^{-1}$. $^{[51]}$ Another novel immunological approach was developed by Shi and co-workers in which microbubbles enveloped with antiEpCAM were used for CTC isolation. ${ }^{[43]}$

Affinity-based capture also holds negative selection under its umbrella, in which the target cells are made to pass through WBCs, are targeted by antibodies against CD45, ${ }^{[52,53]}$ and/or CD15. ${ }^{[53]}$ The advantage of negative selection lies in its capability of isolating CTCs that may or may not express epithelial markers. ${ }^{[53]}$ This approach has been used in the CTC-iChip, ${ }^{[53]}$ and by Wu et al. ${ }^{[54]}$ Casavant et al. used magnetic beads coated with anti-CD45 as a means of depleting white blood cells as a precursor to CTC enrichment. ${ }^{[52]}$

Recently, the limitation of throughput for immuno-affinity isolation of CTCs has been addressed by a number of devices operating at high flow rates. Of note are the demonstrations of the CTC-iChip ${ }^{[53]}$ which is a combination of affinity and size-based isolation, an integrated high-throughput device by Liu et al., ${ }^{[5]}$ immunomagnetic isolation at $10 \mathrm{~mL} \mathrm{~h}^{-1},{ }^{[51]}$ and the OncoBean Chip, a purely affinity isolation device operating at $10 \mathrm{~mL} \mathrm{~h}^{-1}$ developed in our lab. ${ }^{[56]} \mathrm{An}$ in vivo CTC detection technology, the GILUPI CellCollector, employing anti-EpCAM to capture CTCs in venous blood flow is also an 
Table 1. Summary of micro and nanofluidic technologies for CTC isolation and analysis.

\begin{tabular}{|c|c|c|c|c|c|c|}
\hline \multicolumn{7}{|c|}{ Affinity-based isolation } \\
\hline Technology & Capture method & Flow rate & Capture efficiency details & Purity & Clinical utility & Reference \\
\hline CTC-chip & Affinity (EpCAM) & $1 \mathrm{~mL} \mathrm{~h}^{-1}$ & $\begin{array}{l}>60 \% \text { with different concentrations } \\
\text { of } \mathrm{NCl}-\mathrm{H} 1650 \text { cells (lung) }\end{array}$ & $50 \%$ & $\begin{array}{l}\text { Tested with } 116 \text { patient samples } \\
\text { (lung, prostate, pancreatic, breast } \\
\text { and colon cancers) }\end{array}$ & [21] \\
\hline HB-chip & Affinity (EpCAM) & $1.2 \mathrm{~mL} \mathrm{~h}^{-1}$ & $92 \%$ with PC3 cells (prostate) & $14 \%$ & $\begin{array}{l}\text { Tested with } 15 \text { prostate cancer } \\
\text { patient samples }\end{array}$ & [33] \\
\hline GEDI chip & Affinity (PSMA) & $1 \mathrm{~mL} \mathrm{~h}^{-1}$ & $\begin{array}{l}85 \% \text { in blood with LNCaP cells } \\
\text { (prostate) }\end{array}$ & $68 \%$ & $\begin{array}{c}\text { Tested with } 20 \text { prostate cancer } \\
\text { patient samples }\end{array}$ & [47] \\
\hline NanoVelcro Chip & Affinity (EpCAM) & $0.5 \mathrm{~mL} \mathrm{~h}^{-1}$ & $\begin{array}{l}>80 \% \text { with LNCaP, PC3, C4-2 cells } \\
\text { (prostate) }\end{array}$ & - & $\begin{array}{l}\text { Tested with } 40 \text { prostate cancer } \\
\text { patient samples }\end{array}$ & [42] \\
\hline Graphene oxide chip & Affinity (EpCAM) & $1 \mathrm{~mL} \mathrm{~h}^{-1}$ & $>85 \%$ with MCF7 cells (breast) & - & $\begin{array}{l}\text { Tested with } 20 \text { patient samples } \\
\text { (breast, pancreatic and lung cancer) }\end{array}$ & [41] \\
\hline OncoBean Chip & Affinity (EpCAM) & $10 \mathrm{~mL} \mathrm{~h}^{-1}$ & $\begin{array}{l}>80 \% \text { with } \mathrm{H} 1650 \text { (lung) and MCF7 } \\
\text { (breast) cancer cell lines }\end{array}$ & - & $\begin{array}{l}\text { Tested with } 6 \text { patient samples (lung, } \\
\text { breast and pancreatic cancer) }\end{array}$ & [56] \\
\hline \multicolumn{7}{|c|}{ Label-free isolation } \\
\hline Device Name & Capture method & Flow rate & Capture efficiency details & Purity & Clinical utility & Reference \\
\hline p-MOFF & $\begin{array}{c}\text { Size-based } \\
\text { (Hydrodynamic) }\end{array}$ & $0.6 \mathrm{~mL} \mathrm{~min}{ }^{-1}$ & $\begin{array}{l}93.75 \% \text { with MCF-7 } 91.60 \% \text { with } \\
\text { MDA-MB-231 }\end{array}$ & - & $\begin{array}{l}\text { Tested with } 24 \text { breast cancer patient } \\
\text { samples }\end{array}$ & [97] \\
\hline $\mathrm{N} / \mathrm{A}$ & $\begin{array}{l}\text { Size-based (Filter Pilar } \\
\text { type) }\end{array}$ & $\begin{array}{l}\text { Operating pressure } \\
\text { of } 5 \mathrm{KPa}\end{array}$ & $\begin{array}{c}80 \% \text { with AGS, N87, HepG2, Huh7, } \\
\text { CAL27, and FADU }\end{array}$ & $\begin{array}{l}89 \% \text { mean } \mathrm{T} \\
\text { purity }\end{array}$ & $\begin{array}{c}\text { Tested with } 5 \text { metastatic lung cancer } \\
\text { patient samples }\end{array}$ & [87] \\
\hline N/A & $\begin{array}{c}\text { Size-based } \\
\text { (Hydrodynamic) }\end{array}$ & $3 \mathrm{~mL} \mathrm{~h}^{-1}$ & $>85 \%$ with MCF-7 & - & $\begin{array}{l}\text { Tested with } 20 \text { metastatic lung } \\
\text { cancer patient samples }\end{array}$ & [60] \\
\hline SB microfilter & $\begin{array}{l}\text { Size-based (Filter Pore } \\
\text { type) }\end{array}$ & Gravity driven flow & $\begin{array}{c}83 \pm 3 \% \text { with MCF-7 } 78 \pm 4 \% \text { with } \\
\text { MDA-MB-231 }\end{array}$ & n & $\begin{array}{l}\text { Tested with } 6 \text { metastatic breast } \\
\text { cancer mouse model and } 1 \\
\text { metastatic colorectal cancer patient } \\
\text { samples }\end{array}$ & [88] \\
\hline N/A & $\begin{array}{l}\text { Size-based (Filter Pore } \\
\text { type) }\end{array}$ & $>225 \mathrm{~mL} \mathrm{~h}^{-1}$ & $\begin{array}{c}>90 \% \text { with RT4, T24, HT-1080, } \\
\text { LNCaP, MCF-7, SK-BR-3 and } \\
\text { MDA-MB-231 }\end{array}$ & - & $\begin{array}{l}\text { Tested with } 51 \text { patient samples } \\
\text { (prostate, colorectal, breast and } \\
\text { bladder cancer) }\end{array}$ & [83] \\
\hline Vortex Chip & $\begin{array}{c}\text { Size-based } \\
\text { (Hydrodynamic) }\end{array}$ & $7.5 \mathrm{~mL} / 20 \mathrm{~min}$ & $\begin{array}{c}15.9 \% \text { A5 } 4816.8 \% \text { OVCAR5 } 17.7 \% \\
\text { MCF-7 17.7\% M395 18.2\% PC3 }\end{array}$ & $57 \%-94 \%$ & $\begin{array}{l}\text { Tested with } 12 \text { patient samples } \\
\text { (breast and lung cancer) }\end{array}$ & [96] \\
\hline N/A & $\begin{array}{l}\text { Size-based (Centrifugal } \\
\text { Force) }\end{array}$ & $\begin{array}{l}3 \mathrm{~mL} \text { whole blood } \\
\text { in } 20 \mathrm{~s} \\
(2400 \mathrm{rpm})\end{array}$ & $61 \%$ with MCF-7 & - & $\begin{array}{l}\text { Tested with } 23 \text { patient samples } \\
\text { (lung and gastric cancer) }\end{array}$ & [93] \\
\hline N/A & Size-based (DEP) & $10 \mathrm{~mL} \mathrm{~h}^{-1}$ & $\begin{array}{c}70 \%-80 \% \text { With MDA-MB- } 435 \text { and } \\
\text { MDA-MB-231 }\end{array}$ & - & $\begin{array}{c}\text { Tested with late stage colon cancer } \\
\text { patients }\end{array}$ & [102] \\
\hline N/A & $\begin{array}{c}\text { Size-based } \\
\text { (DC-Impedance) }\end{array}$ & $13 \mu \mathrm{L} \mathrm{min}-1$ & $88 \%$ with OVCAR-3 & - & $\begin{array}{c}\text { Tested with } 24 \text { breast cancer } \\
\text { patients samples }\end{array}$ & [103] \\
\hline $\begin{array}{l}\text { Dean Flow } \\
\text { Fractionation }\end{array}$ & $\begin{array}{c}\text { Size-based } \\
\text { (Hydrodynamic) }\end{array}$ & $7.5 \mathrm{~mL}$ blood $/ 8 \mathrm{~min}$ & $\begin{array}{c}>80 \% \text { with MDA-MB-231, MCF-7 } \\
\text { and T24 }\end{array}$ & $\begin{array}{l}\approx 4 \log \\
\text { depletion }\end{array}$ & $\begin{array}{l}\text { Tested with } 10 \text { patient samples } \\
\text { (breast and lung cancer) }\end{array}$ & [98] \\
\hline N/A & $\begin{array}{l}\text { Size-based } \\
\text { (Hydrodynamic) }\end{array}$ & $7.5 \mathrm{~mL} / 10 \mathrm{~min}$ & $87.6 \%$ with MCF-7 $76.4 \%$ with T24 & - & $\begin{array}{l}\text { Tested with } 10 \text { patient samples } \\
\text { (breast and lung cancer) }\end{array}$ & [99] \\
\hline N/A & $\begin{array}{c}\text { Size-based (tilted-angle } \\
\text { standing surface acoustic } \\
\text { waves (taSSAWs) }\end{array}$ & $20 \mu \mathrm{L} \mathrm{min}-1$ & $\begin{array}{l}>83 \% \text { with MCF-7, HeLa, } \\
\text { UACC } 903 \text { M-GFP, LNCaP }\end{array}$ & $\begin{array}{l}\approx 90 \% \\
\text { removal rate } \\
\text { of WBCs }\end{array}$ & $\begin{array}{c}\text { Tested with } 3 \text { metastatic breast } \\
\text { cancer patients }\end{array}$ & {$[72,73]$} \\
\hline
\end{tabular}

example of a system that demonstrates CTC isolation even under high physiological shear stresses $\left(20 \mathrm{~mL} \mathrm{~min}^{-1}\right)$ present in the circulation. ${ }^{[57]}$

\subsection{Advantages of Immuno-Affinity-Based Approaches}

CTC enumeration, albeit a very important part of CTC studies, is only one aspect of the clinical utility of these cells. And while CTC numbers have been correlated to prognosis, ${ }^{[19]}$ characterization of these cells is still an unmet and essential demand. With numerous technologies for CTC enrichment and enumeration in development, studies are now shifting gear toward addressing what these cells are capable of. With this in mind, a number of recent findings have been published showing CTCs' ability to metastasize, ${ }^{[58]}$ their tumor forming potential, ${ }^{[12,59]}$ their potential utility as agents showing drug response, ${ }^{[12]}$ and their clonal heterogeneity. ${ }^{[13]}$ 

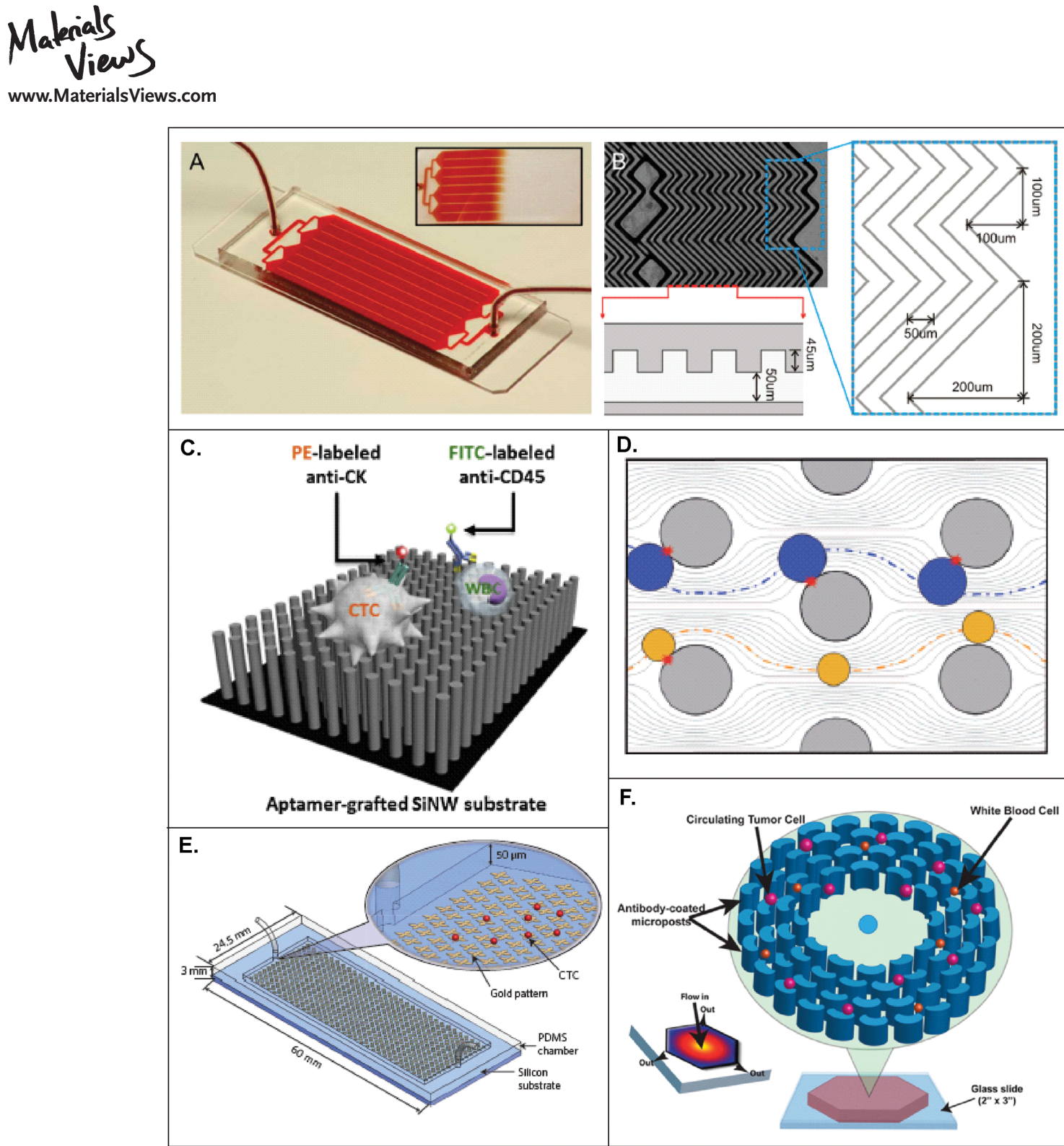

Figure 2. Affinity-based micro and nanofluidic technologies for CTC isolation. A,B) The HB chip is designed to capture CTCs by enhancing mixing inside the chamber Reproduced with permission. ${ }^{[33]}$ Copyright 2010, PNAS. C) The NanoVelcro chip showing nanostructures coated with antibody for cell capture Reproduced with permission. ${ }^{[42]}$ Copyright 2013, Elsevier. D) Image of the flow dynamics in the GEDI chip that uses PSMA to capture CTCS Reproduced with permission. ${ }^{[47]}$ Copyright 2009, Royal Society of Chemistry. E) The design of the graphene oxide chip showing gold nanoposts for CTC capture Reproduced with permission. ${ }^{[41]}$ Copyright 2013, Nature Publishing Group. F) Radial flow OncoBean Chip showing antibody-coated microposts for CTC capture Reproduced with permission. ${ }^{[56]}$ Copyright 2014, John Wiley and Sons.

Baccelli et al. showed that CTCs are a diverse pool of cells, and may contain a certain population of metastasis initiating cells which would be the aggressive cells. ${ }^{[58]}$

Because of the principle of capture, affinity-based isolation offers very high specificity of the recovered CTCs since the target CTCs are validated by the capture antigen in addition to identification by immunostaining procedures. The method also enables recovery of an assorted pool of CTCs, regardless of morphological considerations such as size. Whilst many size-based technologies may capture CTCs with high yields, the wide variability of CTC sizes previously reported ${ }^{[10,29,60]}$ makes the smaller CTCs highly probable to be missed in size-based techniques which are usually biased toward the larger cells. Affinity-based methods can indiscriminately capture such populations, and are also capable of doing the same without the need for preprocessing steps such as dilution or red blood cell lysis, invariably required by physical separation techniques. ${ }^{[60]}$ The specificity also allows for better downstream analysis which may have clinical utility. One such application was demonstrated by Maheswaran et al. who performed downstream sequencing studies on CTCs captured on an affinity platform (the CTC-chip) from lung cancer patients. ${ }^{[23]}$

Affinity capture also allows high purity of the recovered CTCs. ${ }^{[47]}$ Since these cells are rare, any downstream applications are dictated by the accompaniment of contaminating blood cells. The specificity of CTC capture by affinity techniques is also reflected in the retained background cells. The targeted capture not only allows for low nonspecific retention but also washes away most red blood cells, eliminating the need for red blood cell lysis as a precursor to blood analysis. The highly specific and pure CTC yield facilitated by 
immuno-capture combined with the viability is also conducive to CTC culture and expansion. ${ }^{[61]}$

In order to efficiently study the diverse properties of CTCs, their isolation needs to be tailor-made to answer the relevant biological questions. Immuno-affinity offers a beautiful platform for this purpose as antibody-based capture techniques can be customized to target different subpopulations of CTCs. A combination of antibodies consisting of the traditional anti-EpCAM with another marker, or successive captures with the respective individual antibodies can yield the desired populations. ${ }^{[38,62]}$ For instance, Riethdorf et al. utilized HER2 as a target agent to identify CTCs among patients undergoing neoadjuvant treatment for a HER2 inhibitor. ${ }^{[8]}$ Pecot et al. used an interesting cocktail of antibodies to target both epithelial cells and potential CTCs undergoing EMT. ${ }^{[38]}$ Affinity-based capture techniques are thus widely capable of specific targeting of cell subpopulations, an area requiring deeper attention as more and more studies illuminate tumor cell heterogeneity. ${ }^{[14]}$

Affinity-based methods also offer high utility with respect to capturing rare events such as CTC clusters. ${ }^{[13,33]}$ These clusters may sometimes be larger than the detection range of physical separation techniques and/or may clog the channels. ${ }^{[63]}$ CTC clusters are believed to have more metastasizing capability than single cells in the circulation. ${ }^{[13,64]}$ Larger clusters containing a heterogeneous mix of cells may also be captured if some of the cells in the cluster express the target antigen, thereby achieving capture of potentially "unfamiliar" populations using "known" targets. Furthermore, the generally lower shear experienced by cells in immuno-affinity capture $^{[56]}$ also enables collection of CTCs that are possibly circulating in conjunction with platelets. Platelets are believed to be implicated in metastasis and platelet-enveloped CTCs may be important in disease progression as they are able to evade immune surveillance. ${ }^{[13,65-67]}$

\subsection{Disadvantages of Affinity-Based Approaches}

Traditionally preferred for CTC isolation, ${ }^{[15]}$ affinity methods have validated their utility in a number of CTC analyses studies. However, they suffer from a few limitations. Throughput is a major concern with antibody-based CTC recovery chips such as the CTC-chip and HB-chip. ${ }^{[53]}$ This is due to the limited shear conditions under which affinity binding occurs. ${ }^{[56]}$ Microfluidic flow-based affinity capture requires optimal velocity and shear conditions for antibody-antigen binding. ${ }^{[21,36]}$ A very high shear may disrupt any bonds if formed, while a very low shear is conducive to nonspecific cell binding. ${ }^{[56]}$ An optimal binding condition would provide adequate capture of target cells, with minimal amount of blood cells retained; in other words, a high efficiency with minimal contamination. These optimal conditions limit the velocity of flow during capture. The CTC-chip and its successors operating on similar principles therefore had an operating flow rate of $1-3 \mathrm{~mL} \mathrm{~h}^{-1} .{ }^{[56]}$ In the CTC-chip itself, increasing the flow rate from 1 to $3 \mathrm{~mL} \mathrm{~h}^{-1}$ diminished the capture efficiency. ${ }^{[21]}$ This limits the blood volume that can be analyzed due to the time constraints it places on the experiments. Of late, a number of technologies have overcome the throughput limitation by introducing novel designs to circumvent the issue of optimal binding conditions. ${ }^{[56]}$

EMT transition, a process in which cells lose their epithelial characteristics and become more mesenchymal, is believed to be an important process hampering the study of CTCs on the basis of EpCAM alone. ${ }^{[10]}$ As these cells undergo the change, their EpCAM expression decreases, and they may be missed by EpCAM targeted capture. ${ }^{[10,68]}$ These EMT-undergoing cells are believed to be important players in metastasis ${ }^{[68]}$ and may be able to provide useful information about the dissemination of tumor cells. ${ }^{[10]}$ Combinations of antibodies are therefore being employed to capture not only epithelial cells, but also the mesenchymal ones. ${ }^{[38]}$

Many microfluidic affinity-based technologies employ surface modifications for antibody conjugation and immobilization. ${ }^{[21]}$ This poses problems as many of the bonds are irreversible and cannot be easily degraded and/or may affect the viability of these rare cells themselves in the process. ${ }^{[69]}$ Subsequent assays such as single cell analysis and CTC derived xenografts may not be feasible in such cases due to cell release difficulties. ${ }^{[69]}$ Many genetic analyses performed on CTCs thus depend on nucleic acid extraction from the pool of cells captured on these devices, which may create background noise as the captured populations contain impurities such as blood cells. ${ }^{[1]}$

\section{Label-Free Isolation of CTCs}

\subsection{How It Works}

The use of physical properties allows a label-free isolation, aimed to overcome biased cell selection using biologicalbased separation methods. This approach allows the isolation of intact cells without stressing their plasma membrane through antibody binding, which is a vital aspect for further downstream characterization of CTCs. This method tends to exploit the size differences among CTCs and other blood components. More specifically, CTCs have been shown to have a diameter of $13-25 \mu \mathrm{m}$ in diameter, ${ }^{[32]}$ larger than the rest of the blood cells such as leukocytes with diameter ranges from 8 to $11 \mu \mathrm{m},{ }^{[70]}$ and red blood cells (RBCs) with diameters in the range of 5-9 $\mu \mathrm{m} .{ }^{[71]}$ Label-free approaches can be classified into three main categories- filtration, hydrodynamic chromatography, and dielectrophoresis (DEP). In addition, other novel methods exploiting the physical properties of CTCs including acoustic separation have also been recently developed. ${ }^{[72-74]}$

\subsection{Biomarker-Independent Technologies for the Isolation of CTCS}

Compared to immuno-affinity-based approaches, the biomarker-independent CTC isolation technologies are still evolving. While many of these have been optimized with 
cancer cell lines, few have been validated with clinical specimens. The use of cancer cell lines as a CTC model makes an ideal model for the optimization of a new technology. However, cell lines do not represent the heterogeneous morphology found in clinical specimens. ${ }^{[75]}$ Some subpopulations of CTCs will indeed be more deformable and smaller than cancer cell lines. Therefore, using cell lines to optimize new technologies may not serve as a true test of efficiency as their clinical utility will only be determined by testing clinical samples. ${ }^{[76]}$ Here, we summarize the recent label-free microfluidic technologies that have been (i) characterized using cancer cell lines and (ii) clinically proven to work by isolating CTCs from patient samples over the past five years (Figure 3).

\subsubsection{Filtration Methods}

Membrane-based filtration is one of the first methods used for isolating CTCs, being a relatively straightforward and low-cost technique. This method captures target cells using constrictions based on cell size and deformability. ${ }^{[76}$ Most of the reported membranes have pore sizes around $7-8 \mu \mathrm{m}$
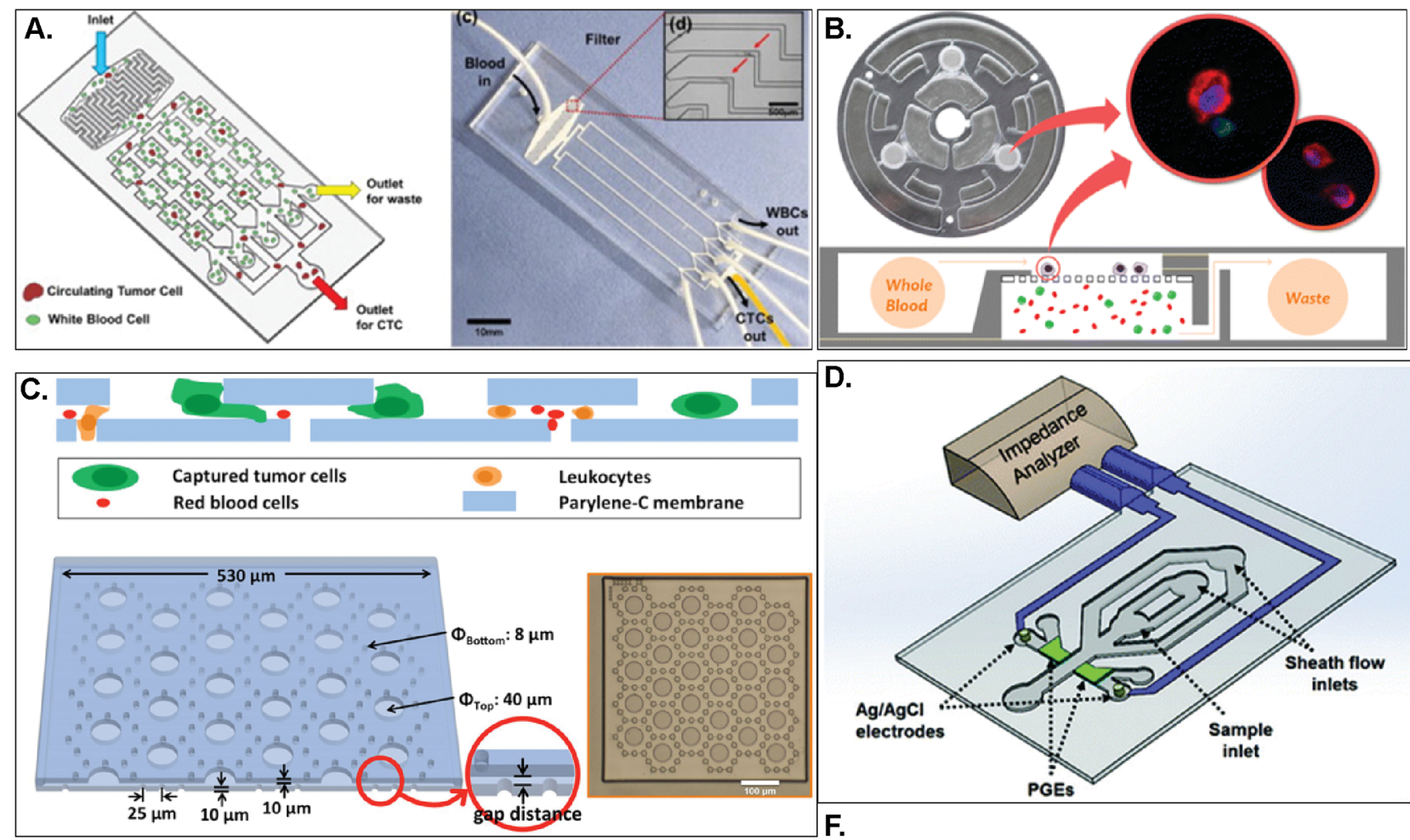

D.
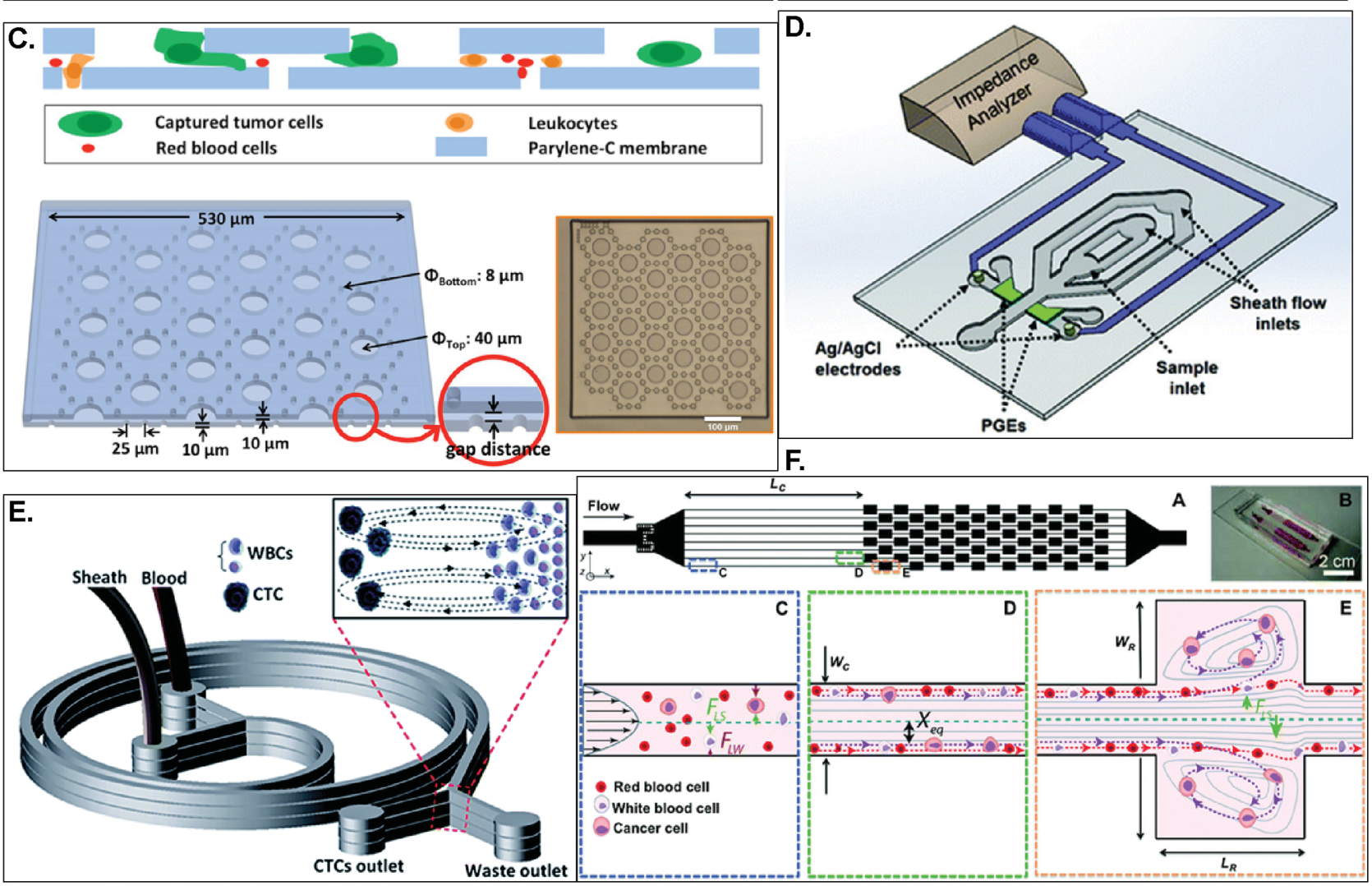

Figure 3. Label-free micro and nanofluidic technologies for CTC isolation. A) The parallel multiorifice flow fractionation (p-MOFF) device allows label-free isolation of CTCs by inertial forces through a series of contraction and expansion structures. Reproduced with permission. ${ }^{[97]}$ Copyright 2013, Elsevier. B) Centrifugal microfluidic device uses a track-etched polycarbonate (PC) membrane filter to isolate CTCs based on size. Reproduced with permission. ${ }^{[93]}$ Copyright 2014, American Chemical Society. C) The separable bilayer (SB) microfilter uses biocompatible polymer parylene-C to enrich CTCs. Reproduced with permission. ${ }^{[88]}$ Copyright 2014, the authors. D) The use of two polyelectrolytic gel electrodes under low DC voltages allows the DC impedance-based microcytometer to isolate CTCs. Reproduced with permission. ${ }^{[103]}$ Copyright 2013, Royal Society of Chemistry. E) The ultrahigh-throughput spiral takes advantages of inertial focusing inside the device to isolate CTCs. Reproduced with permission. ${ }^{[99]}$ Copyright 2014, Royal Society of Chemistry. F) Vortex Chip uses microscale vortices and inertial focusing for extraction of CTCs from blood. Reproduced with permission. ${ }^{[96]}$ Copyright 2013, Royal Society of Chemistry. 
diameter, with few reporting on membranes with pore size diameters up to $11 \mu \mathrm{m} .{ }^{[77]}$ Vona et al. proposed ISET (isolation by size of epithelial tumor cells), a commercially available technology that uses a polycarbonate membranefilter. ${ }^{[78]}$ This is a filtration method that uses $8 \mu \mathrm{m}$ cylindrical pores to capture CTCs. However, its large variability in CTC capture efficiency and low purity caused by membrane clogging left opportunities for further improvement. Integrating microfabricated filtration membranes into microfluidic devices has since emerged as an optimized approach for CTC separation. Materials such as polycarbonate, ${ }^{[79-81]}$ parylene-C, ${ }^{[82-84]}$ nickel, ${ }^{[85]}$ and silicon ${ }^{[86]}$ have demonstrated to provide the appropriate membrane surface area and porosity to enhance CTC capture.

In 2010, Lin et al. published one of the first label-free methods to be tested using clinical samples. ${ }^{[83]}$ With a total of 57 human samples from various cancer types, this parylene membrane microfilter identified CTCs in 51 out of 57 patients compared to only 26 patients with the CellSearch method. Tan et al. published a label-free biochip that uses physical structures or pillars to trap single cells without having cell buildup. ${ }^{[87]}$ Lim et al. developed a silicon microsieve that contains a dense array of pores to isolate CTCs at a flow rate

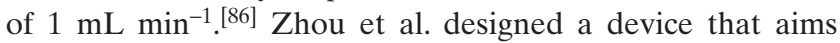
for the filter-based capture of viable cells with the use of a design that incorporates a low mechanical stress, termed the separable bilayer (SB) microfilter. ${ }^{[88]}$ The high viability of enriched CTCs using the SB microfilter allows for functional analysis and on-chip expansion of CTCs, further discussed in the next section of this review.

\subsubsection{Hydrodynamic Methods}

Hydrodynamic-based approaches have shown the highest throughput capability. ${ }^{[77]}$ Recently, inertial migration of particles has been introduced and applied in various studies to achieve high throughput separation based on particle size. ${ }^{[89]}$ Briefly, the particles migrate and are focused in microchannels due to the equilibrium of two inertial lift forces which act on the particles in opposite directions- shear gradient lift force and wall lift force. ${ }^{[89]}$ Some other technologies exploit a secondary flow called Dean flow that takes place in curvilinear channels. ${ }^{[90]}$ In addition, hydrophoresis is another approach that makes use of rotational flow for separating particles based on size. ${ }^{[91]}$ Another approach, termed deterministic lateral displacement, in which microposts are strategically placed to divide the flow into several laminar streams, are also used for separation of CTCs from blood cells. ${ }^{[92]}$ Regardless of the type of hydrodynamic-based technologies, the goal is to impart different flow velocities based on cell size differences to separate the target cells with high efficiency. Lee et al. developed a lab-on-a disc platform that utilizes centrifugal force to rapidly transfer unprocessed whole blood samples from one chamber to another. ${ }^{[93]}$ The selective isolation of CTCs was achieved through the use of a commercially available track-etched polycarbonate membrane filter on a lab-on-a-disc system. Hou et al. developed a spiral microchannel for separation of CTCs using centrifugal forces, a principle known as Dean Flow Fractionation. ${ }^{[60]}$ Using this device, they were able to detect a subpopulation of CTCs that were positive for CD133, a phenotypic marker characteristic of stem-like behavior in lung cancer cells. ${ }^{[94]}$ Furthermore, this device was the first inertial device to demonstrate the capacity to process blood samples with a high hematocrit. Our group also demonstrated theoretical investigation of inertial separation of CTCs using cascaded spiral microfluidics. ${ }^{[95]}$ Sollier et al. developed the Vortex Chip, which uses microscale vortices and inertial focusing to isolate CTCs. ${ }^{[96]}$ Hyun et al. developed a parallel multiorifice flow fractionation (p-MOFF) device in which contraction/expansion microchannels were placed in a parallel configuration for CTC separation. ${ }^{[97]}$ This device was shown to use inertial forces to isolate CTCs from 24 breast cancer patients at a high throughput. ${ }^{[97]}$ Warkiani et al. developed the trapezoid chip, which uses a trapezoidal design and exploits Dean forces and lift forces to isolate CTCs. ${ }^{[98]}$ More recently, Warkiani et al. reported an ultrahigh-throughput spiral device ${ }^{[99]}$ consisting of three stacked spiral microfluidic chips with two inlets and two outlets, in which the combination of the inertial and Dean forces focuses the cells at certain equilibrium positions of the channel cross-section. Khoo et al. published an improved version of this technology with clinical validation using a large number of clinical samples, and also performed downstream immunophenotyping and molecular analyses from isolated CTCs, ${ }^{[100]}$ further discussed in the next section.

\subsubsection{Dielectrophoresis Methods}

DEP methods are used for isolating CTCs based on cell membrane and cell dielectric properties. Using this approach CTCs are generally separated by their response to nonuniform electrical fields, since the polarizability of a cell relies on its composition, morphology and the frequency of the applied electric field. ${ }^{[101]}$ Therefore, using DEP-based devices allows the identification of cells with different phenotypes. However, compared to the two previously described approaches, DEP-based technologies do not show high selectivity and have low throughputs $\left(<1 \mathrm{~mL} \mathrm{~h}^{-1}\right)$. ${ }^{[76]}$

Shim et al. used a continuous flow microfluidic processing chamber into which CTCs are isolated from clinical samples using a combination of DEP, sedimentation, and hydrodynamic lift forces. ${ }^{[102]}$ Choi et al. designed a novel DC (direct current) impedance-based microcytometer that detects changes in DC impedance and exploits size differences between CTCs and blood cells. ${ }^{[103]}$

\subsection{Advantages of Label-Free Approaches}

Physical CTC separation methods have the potential to address the shortcomings involved in biological marker-based separation methods. Overcoming biased cell selection using molecular markers permits heterogeneity studies on CTCs, where different subpopulations can be analyzed. As previously mentioned, CTCs that have undergone EMT are associated with a loss of expression for epithelial markers, such 
as EpCAM and Cytokeratin. As a result, the most aggressive cancer cells could potentially be the least likely to be captured and identified using EpCAM-based technologies. ${ }^{[32,38]}$

Isolated CTCs can be collected without compromising cell viability or gene expression, which in turn enables their molecular characterization. For instance, Shim et al. used continuous flow dielectrophoretic field flow fractionation method and also performed molecular studies on isolated CTCs. ${ }^{[102]}$ For a colon primary tumor, $10 \%$ of the stained cells had the KRAS G13D mutation, which also reflected the number of cells that were stained positive for Cytokeratin. Warkiani et al. performed DNA fluorescence in situ hybridization (FISH) to evaluate the HER2 status of isolated CTCs from breast cancer patients using their trapezoid chip. ${ }^{[98,99]}$ Their results showed that the presence of HER2+ CTCs varied across samples and was also observed in samples derived from patients with HER2- tumors ( 2 out of 5). A later spiral technology by Warkiani et al. characterized CTCs that were isolated from lung and breast cancer patients by immunophenotyping using cell markers such as Pan-cytokeratin, CD45, CD44, CD24, and EpCAM, FISH for EML4-ALK fusion or targeted somatic mutation analysis. ${ }^{[99]}$ They also demonstrated the ability to find matching mutations of the EGFR gene in CTCs, cell-free DNA, and tumor biopsy specimens. ${ }^{[100]}$

Unlike most immuno-affinity-based isolation systems which only allow on-chip growth of $\mathrm{CTCs}^{[61]}$ due to difficulties in postseparation retrieval, ${ }^{[69]}$ inertial-based technologies simplify CTC culture by using off-chip standard cell culture techniques since cells can be recovered in suspension. This advantage gives rise to multiple CTC expansion approaches, such as the use of extracellular matrix (matrigel or collagen) for CTCs growth or a 3D culture system. ${ }^{[61]}$ Sollier et al. showed that A549 cells processed with the Vortex Chip and collected in a well-plate proliferate over 3 days. ${ }^{[96]}$ Similarly Hou et al. used their device to demonstrate this advantage by successfully culturing sorted MCF-7 cells for 5 days. ${ }^{[60]}$ Moreover, they also show the retrieval of intact MCF-7 cell clusters. Despite the high throughput of the label-free devices, these technologies are still able to preserve cell clusters, which are of greater interest to study the metastatic ability of CTCs. ${ }^{[13,104]}$

In vivo application of label-free technologies is still very limited. In one study Zhou et al. used their SB microfilter device to perform the only in vivo study currently published using a label-free microfluidic device. ${ }^{[88]}$ This group demonstrated capture and expansion of CTCs originated from two mouse model systems from 4T1 and 4T07 cells. They demonstrated tumor formation after injection of 4T1 CTCs and 4T07 CTCs into BALB/C mice. Their study also showed similar tumorigenicity for both CTCs recovered by the SB microfilter.

\subsection{Disadvantages of Label-Free Approaches}

Although on average CTCs are shown to be larger than leukocytes, there is a significant overlap in the size of CTCs and leukocytes that may hinder label-free separation efforts. The FDA-approved CellSearch system has detected CTCs with cell diameters $\approx 4 \mu \mathrm{m} .{ }^{[25]}$ Marinnucci et al. also reported findings on CTCs that were the same size or smaller than leukocytes. ${ }^{[105]}$ This variability in size can cause the loss of CTCs or, to overcome such problem, low sample purity. Although greatly studied, filter-based approaches encounter clogging difficulties when processing large sample volumes. ${ }^{[106]}$ This results in flow rate discrepancies, which could endanger important performance characteristics ranging from device reproducibility to cell viability for postprocessing analysis. Regarding the use of DEP, one concern is the effect on the viability of CTCs due to the generation of gases like hydrogen and oxygen. Moreover, elevated temperatures may also affect cell viability. ${ }^{[107]}$

\section{The Future}

The field of microfluidics and CTCs is rapidly evolving. In fact, last year the journal Lab on a Chip published a complete CTC-themed issue that highlights some of the new technologies along with review papers targeting different aspects, both technical and clinical. ${ }^{[108]}$ Both affinity and size-based methods of CTC isolation need dramatic improvements to their systems to enable highly efficient CTC recovery. ${ }^{[1]}$ Affinity isolations have the potential to provide key information that may be missed by size-based techniques as outlined in their advantages above. Refinements such as increasing throughputs, targeting multiple populations with the use of multiple antibodies may be the important steps needed to further improve these technologies. Use of novel materials and reversible conjugation of antibodies that may enable CTC release will offer more robust CTC analysis modules, as these CTCs can then be utilized for downstream assays. ${ }^{[69,109]}$ Using immuno-capture methods, different populations of CTCs can be segregated for further analysis that may be able to identify tumorigenic CTCs, such as xenograft studies. ${ }^{[110]}$ As for label-free technologies, their future is driven by exploiting the physical differences between CTCs and leukocytes, with the goal of achieving selective separation of CTCs. For example, cell deformability can be combined with CTC size properties to develop new label-free technologies. ${ }^{[76]}$ Regardless of the technological approach, emerging technologies should not compromise throughput or sensitivity, while still targeting heterogeneous CTCs.

Past the improvement upon current microfluidic technologies, we predict an increase in effort on the molecular understanding of CTCs, encompassing multiple downstream analyses that advances personalized treatment. Comprehensive investigation of CTCs is hampered by their low numbers, making this one of the biggest challenges in this field. ${ }^{[30]}$ For better understanding of CTCs, we expect to see an increase in technologies that not only aim for the isolation of such cells, but also to perform in situ expansion on such devices. For example, Zhang et al. expanded CTCs from early lung cancer patients using a 3D coculture device that used cancer associated fibroblasts and a combination of collagen and matrigel to resemble the tumor microenvironment. ${ }^{[61]}$ Moreover, we predict an increase of label-free methods for straightforward retrieval of CTCs from microfluidic chips, leading to ex vivo expansion. Recently, several groups have successfully 
performed ex vivo expansion of CTCs from breast cancer ${ }^{[111]}$ and from colon cancer. ${ }^{[112]}$ Overcoming the limitation of low numbers of CTCs by expanding them will allow for phenotypic and genomic characterization of CTCs, which in turn will lead to personalized treatment strategies. The establishment of cell lines from cancer patients could guide the course of drug therapy at an individual level to ensure optimal treatment outcome.

Heterogeneity among CTCs makes their isolation and characterization a challenging task. The molecular characterization of CTCs has exposed information on the genotype and phenotype of these tumor cells and demonstrated a striking heterogeneity of CTCs. ${ }^{[113]}$ Thus, the present setback is the identification of the functional properties of the different CTC subsets. This could be achieved through the use of functional assays that reveal the biology of CTCs, with particular emphasis on the discovery of the most aggressive subset of CTCs. At present, such assays are limited by the very low concentration and yield of CTCs. Single cell studies could serve as an essential tool to assess the heterogeneity among CTCs. The study of single CTCs by their molecular characterization provides high clinical relevance by potentially aiding in early cancer detection and revealing new therapeutic targets for personalized medicine. ${ }^{[114,115]}$

While CTC enumeration has shown tremendous potential in terms of clinical utility, ${ }^{[116]}$ researchers are now exploring their validity as more than just an enumerable measure of disease intensity or spread. The prognostic and diagnostic utilities of CTCs are now an area of extensive focus through analysis of gene expression profiles, ${ }^{[117]}$ single cell analysis, ${ }^{[11]}$ RNA and DNA studies, ${ }^{[2,23]}$ and cytogenetics to detect gene amplifications or rearrangements. ${ }^{[118,119]}$ Examining epigenetic modifications and their after effects on the metastatic cascade may be a useful tool for determining therapeutic efficacy. Chimonidou et al. analyzed CTCs and cell-free DNA in breast cancer for methylation of a tumor suppressor gene SOX17 promoter. ${ }^{[120]}$ In another study of breast cancer, methylation of a metastasis suppressor gene was studied in primary tumor and CTCs, and the authors investigated its effect on survival. ${ }^{[121]}$ Whilst the rarity of CTCs offers challenges in enrichment and downstream assay feasibilities, cell free DNA suffer from similar limitations with respect to available amounts. ${ }^{[122]}$ Malara et al. identified CTC subpopulations that are enriched for methylated DNA using folate receptors. Methylation of cancer cells is believed to be implicated in metastasis, and the authors found that patients with high methylation of CTCs had a risk of relapse. ${ }^{[122]}$ Albeit CTC enumeration has seized attention as a possible endpoint in clinical trials due to their prognostic utility, ${ }^{[8]} \mathrm{a}$ comprehensive analysis of the genome and epigenome will likely compliment traditional diagnostic methods and open the arena for more frequent patient monitoring, leading to timely decision making. This also has the potential to circumvent invasive tissue biopsies. ${ }^{[21]}$ CTCs also offer a means of personalized therapeutics through their tumorigenic capabilities. ${ }^{[110]}$ CTC expansion on in vitro microfluidic models, one of which has recently been demonstrated by our group ${ }^{[61]}$ propose a method for testing of drugs or drug combinations, ${ }^{[107,110]}$ which can be used to make quicker decisions for therapeutic management. Resistance to treatment can be monitored similarly by analyzing CTCs. ${ }^{[23]}$ The idea that all of the above could possibly be accomplished through venipuncture, a relatively low discomfort means to achieving a higher end, in a field as vast and challenging as cancer management, is both an exciting and formidable notion. The future of CTCs thus looks promising toward patient-specific tumor monitoring.

\section{Conclusion: Who Wins?}

Affinity and size-based methods have both shown great promise in CTC isolation, with each offering differing perspectives and newer insights into the field. With the advent of new technologies, each aims to overcome the pitfalls of its predecessor with respect to sensitivity, specificity, throughput and/or purity. With a plethora of platforms now available for reliable CTC isolation, the question remains as to which methodology is superior. While this does not have a simple answer, a better question yet would be to ask which methodology would most suit the end user requirements based on the biological questions being asked. An ideal CTC extraction method would be a combination of both techniques- an affinity-based enrichment followed by interrogation of the remaining cells by a size-based method, or vice versa. This would obviate the likely pitfalls of any one technique and potentially offer the versatility of targeted capture through affinity isolation, in addition to addressing biological heterogeneity through size-based retrieval of CTCs. Indeed, a few researchers have shown such promising combination methods, most notably the CTC-iChip by Ozkumur et al., which provides positive selection and negative selection modules for CTC interrogations. ${ }^{[53]}$ This device incorporates size-based separation and immunomagnetic selection (positive or negative). ${ }^{[53]}$ The CTC-iChip is high throughput $\left(8 \mathrm{~mL} \mathrm{~h}^{-1}\right)$ with high capture efficiency ( $97 \%$ ) for both positive and negative settings. Another technology by Liu et al. offers an integration of deterministic lateral displacement along with affinity capture. ${ }^{[55]}$ More recently, an integrated device has been developed in our lab that combines inertial sorting with immunomagnetic capture, which provides yields of very high purity enabling molecular analysis of the enriched CTCs. ${ }^{[123]}$ Such integrated techniques open up opportunities for downstream analyses, especially in studying the tumorigenicity or metastatic capabilities of CTCs. And while the answer is not yet obvious, we do not foresee either of the techniques becoming obsolete since they each bring their own flavors to the table.

\section{Acknowledgements}

V.M. and L.R.-B. contributed equally to this work.

[1] M. Yu, S. Stott, M. Toner, S. Maheswaran, D. A. Haber, J. Cell Biol. 2011, 192, 373.

[2] M. Yu, D. T. Ting, S. L. Stott, B. S. Wittner, F. Ozsolak, S. Paul, J. C. Ciciliano, M. E. Smas, D. Winokur, A. J. Gilman, M. J. Ulman, 
K. Xega, G. Contino, B. Alagesan, B. W. Brannigan, P. M. Milos, D. P. Ryan, L. V. Sequist, N. Bardeesy, S. Ramaswamy, M. Toner, S. Maheswaran, D. A. Haber, Nature 2012, 487, 510.

[3] D. Marrinucci, K. Bethel, A. Kolatkar, M. S. Luttgen, M. Malchiodi, F. Baehring, K. Voigt, D. Lazar, J. Nieva, L. Bazhenova, A. H. Ko, W. M. Korn, E. Schram, M. Coward, X. Yang, T. Metzner, R. Lamy, M. Honnatti, C. Yoshioka, J. Kunken, Y. Petrova, D. Sok, D. Nelson, P. Kuhn, Phys. Biol. 2012, 9, 016003.

[4] K. Pantel, C. Alix-Panabieres, Cancer Res. 2013, 73, 6384.

[5] S. Maheswaran, D. A. Haber, Curr. Opin. Genet Dev. 2010, $20,96$.

[6] L. Wu, X. Qu, Chem. Soc. Rev. 2015, 44, 2963.

[7] L. Khoja, A. Backen, R. Sloane, L. Menasce, D. Ryder, M. Krebs, R. Board, G. Clack, A. Hughes, F. Blackhall, J. W. Valle, C. Dive, Br. J. Cancer 2012, 106, 508.

[8] S. Riethdorf, V. Muller, L. Zhang, T. Rau, S. Loibl, M. Komor, M. Roller, J. Huober, T. Fehm, I. Schrader, J. Hilfrich, F. Holms, H. Tesch, H. Eidtmann, M. Untch, G. von Minckwitz, K. Pantel, Clin. Cancer Res. 2010, 16, 2634.

[9] H. A. Azim Jr., F. Rothe, C. M. Aura, M. Bavington, M. Maetens, G. Rouas, G. Gebhart, C. Gamez, H. Eidtmann, J. Baselga, M. Piccart-Gebhart, C. Ellis, P. Vuylsteke, H. Cure, J. Domont, A. Ferro, J. C. Toral-Pena, E. de Azambuja, C. Sotiriou, S. Di Cosimo, M. Ignatiadis, Breast 2013, 22, 1060.

[10] C. Alix-Panabieres, K. Pantel, Clin. Chem. 2013, 59, 110.

[11] D. T. Ting, B. S. Wittner, M. Ligorio, N. Vincent Jordan, A. M. Shah, D. T. Miyamoto, N. Aceto, F. Bersani, B. W. Brannigan, K. Xega, J. C. Ciciliano, H. Zhu, O. C. MacKenzie, J. Trautwein, K. S. Arora, M. Shahid, H. L. Ellis, N. Qu, N. Bardeesy, M. N. Rivera, V. Deshpande, C. R. Ferrone, R. Kapur, S. Ramaswamy, T. Shioda, M. Toner, S. Maheswaran, D. A. Haber, Cell Rep. 2014, 8, 1905.

[12] M. Yu, A. Bardia, B. S. Wittner, S. L. Stott, M. E. Smas, D. T. Ting, S. J. Isakoff, J. C. Ciciliano, M. N. Wells, A. M. Shah, K. F. Concannon, M. C. Donaldson, L. V. Sequist, E. Brachtel, D. Sgroi, J. Baselga, S. Ramaswamy, M. Toner, D. A. Haber, S. Maheswaran, Science 2013, 339, 580.

[13] N. Aceto, A. Bardia, D. T. Miyamoto, M. C. Donaldson, B. S. Wittner, J. A. Spencer, M. Yu, A. Pely, A. Engstrom, H. Zhu, B. W. Brannigan, R. Kapur, S. L. Stott, T. Shioda, S. Ramaswamy, D. T. Ting, C. P. Lin, M. Toner, D. A. Haber, S. Maheswaran, Cell 2014, 158, 1110.

[14] R. M. Mohamadi, J. D. Besant, A. Mepham, B. Green, L. Mahmoudian, T. Gibbs, I. Ivanov, A. Malvea, J. Stojcic, A. L. Allan, L. E. Lowes, E. H. Sargent, R. K. Nam, S. O. Kelley, Angew. Chem. 2015, 54, 139.

[15] D. A. Haber, V. E. Velculescu, Cancer Discovery 2014, 4, 650.

[16] G. Vona, L. Estepa, C. Beroud, D. Damotte, F. Capron, B. Nalpas, A. Mineur, D. Franco, B. Lacour, S. Pol, C. Brechot, P. Paterlini-Brechot, Hepatology 2004, 39, 792.

[17] A. J. Armstrong, M. S. Marengo, S. Oltean, G. Kemeny, R. L. Bitting, J. D. Turnbull, C. I. Herold, P. K. Marcom, D. J. George, M. A. Garcia-Blanco, Mol. Cancer Res. 2011, 9, 997.

[18] M. Cristofanilli, G. T. Budd, M. J. Ellis, A. Stopeck, J. Matera, M. C. Miller, J. M. Reuben, G. V. Doyle, W. J. Allard, L. W. Terstappen, D. F. Hayes, N. Engl. J. Med. 2004, 351, 781.

[19] M. C. Miller, G. V. Doyle, L. W. Terstappen, J. Oncol. 2010, 2010, 617421.

[20] D. F. Hayes, M. Cristofanilli, G. T. Budd, M. J. Ellis, A. Stopeck, M. C. Miller, J. Matera, W. J. Allard, G. V. Doyle, L. W. Terstappen, Clin. Cancer Res. 2006, 12, 4218.

[21] S. Nagrath, L. V. Sequist, S. Maheswaran, D. W. Bell, D. Irimia, L. Ulkus, M. R. Smith, E. L. Kwak, S. Digumarthy, A. Muzikansky, P. Ryan, U. J. Balis, R. G. Tompkins, D. A. Haber, M. Toner, Nature 2007, 450, 1235.

[22] M. D. Kurkuri, F. Al-Ejeh, J. Y. Shi, D. Palms, C. Prestidge, H. J. Griesser, M. P. Brown, B. Thierry, J. Mater. Chem. 2011, 21, 8841.
[23] S. Maheswaran, L. V. Sequist, S. Nagrath, L. Ulkus, B. Brannigan, C. V. Collura, E. Inserra, S. Diederichs, A. J. Iafrate, D. W. Bell, S. Digumarthy, A. Muzikansky, D. Irimia, J. Settleman, R. G. Tompkins, T. J. Lynch, M. Toner, D. A. Haber, N. Engl. J. Med. 2008, 359, 366.

[24] L. Wu, J. Wang, J. Ren, X. Qu, Adv. Funct. Mater. 2014, 24 , 2727.

[25] W. J. Allard, J. Matera, M. C. Miller, M. Repollet, M. C. Connelly, C. Rao, A. G. Tibbe, J. W. Uhr, L. W. Terstappen, Clin. Cancer Res. 2004, 10, 6897.

[26] E. A. Punnoose, S. K. Atwal, J. M. Spoerke, H. Savage, A. Pandita, R. F. Yeh, A. Pirzkall, B. M. Fine, L. C. Amler, D. S. Chen, M. R. Lackner, Plos One 2010, 5, e12517.

[27] S. Riethdorf, H. Fritsche, V. Muller, T. Rau, C. Schindlbeck, B. Rack, W. Janni, C. Coith, K. Beck, F. Janicke, S. Jackson, T. Gornet, M. Cristofanilli, K. Pantel, Clin. Cancer Res. 2007, 13, 920.

[28] D. T. Miyamoto, R. J. Lee, S. L. Stott, D. T. Ting, B. S. Wittner, M. Ulman, M. E. Smas, J. B. Lord, B. W. Brannigan, J. Trautwein, N. H. Bander, C. L. Wu, L. V. Sequist, M. R. Smith, S. Ramaswamy, M. Toner, S. Maheswaran, D. A. Haber, Cancer Discovery 2012, 2, 995.

[29] Y. Dong, A. M. Skelley, K. D. Merdek, K. M. Sprott, C. Jiang, W. E. Pierceall, J. Lin, M. Stocum, W. P. Carney, D. A. Smirnov, J. Mol. Diagn.: JMD 2013, 15, 149.

[30] J. den Toonder, Lab Chip 2011, 11, 375.

[31] Z. Zhang, S. Nagrath, Biomed. Microdevices 2013, 15, 595.

[32] A. A. Bhagat, H. W. Hou, L. D. Li, C. T. Lim, J. Han, Lab Chip 2011 , $11,1870$.

[33] S. L. Stott, C. H. Hsu, D. I. Tsukrov, M. Yu, D. T. Miyamoto, B. A. Waltman, S. M. Rothenberg, A. M. Shah, M. E. Smas, G. K. Korir, F. P. Floyd Jr., A. J. Gilman, J. B. Lord, D. Winokur, S. Springer, D. Irimia, S. Nagrath, L. V. Sequist, R. J. Lee, K. J. Isselbacher, S. Maheswaran, D. A. Haber, M. Toner, Proc. Nat. Acad. Sci. USA 2010, 107, 18392.

[34] Y. F. Sun, X. R. Yang, J. Zhou, S. J. Qiu, J. Fan, Y. Xu, J. Cancer Res. Clin. Oncology 2011, 137, 1151.

[35] C. Alix-Panabieres, K. Pantel, Lab Chip 2014, 14, 57.

[36] S. Mittal, I. Y. Wong, W. M. Deen, M. Toner, Biophys. J. 2012, $102,721$.

[37] S. D. Mikolajczyk, L. S. Millar, P. Tsinberg, S. M. Coutts, M. Zomorrodi, T. Pham, F. Z. Bischoff, T. J. Pircher, J. Oncol. 2011, 2011, 252361.

[38] C. V. Pecot, F. Z. Bischoff, J. A. Mayer, K. L. Wong, T. Pham, J. Bottsford-Miller, R. L. Stone, Y. G. Lin, P. Jaladurgam, J. W. Roh, B. W. Goodman, W. M. Merritt, T. J. Pircher, S. D. Mikolajczyk, A. M. Nick, J. Celestino, C. Eng, L. M. Ellis, M. T. Deavers, A. K. Sood, Cancer Discovery 2011, 1, 580.

[39] A. A. Adams, P. I. Okagbare, J. Feng, M. L. Hupert, D. Patterson, J. Gottert, R. L. McCarley, D. Nikitopoulos, M. C. Murphy, S. A. Soper, J. Am. Chem. Soc. 2008, 130, 8633.

[40] M. Nora Dickson, P. Tsinberg, Z. Tang, F. Z. Bischoff, T. Wilson, E. F. Leonard, Biomicrofluidics 2011, 5, 34119.

[41] H. J. Yoon, T. H. Kim, Z. Zhang, E. Azizi, T. M. Pham, C. Paoletti, J. Lin, N. Ramnath, M. S. Wicha, D. F. Hayes, D. M. Simeone, S. Nagrath, Nat. Nanotechnol 2013, 8, 735.

[42] Y. T. Lu, L. Zhao, Q. Shen, M. A. Garcia, D. Wu, S. Hou, M. Song, X. Xu, W. H. Ouyang, W. W. Ouyang, J. Lichterman, Z. Luo, X. Xuan, J. Huang, L. W. Chung, M. Rettig, H. R. Tseng, C. Shao, E. M. Posadas, Methods 2013, 64, 144.

[43] S. Hou, L. Zhao, Q. Shen, J. Yu, C. Ng, X. Kong, D. Wu, M. Song, X. Shi, X. Xu, W. H. OuYang, R. He, X. Z. Zhao, T. Lee, F. C. Brunicardi, M. A. Garcia, A. Ribas, R. S. Lo, H. R. Tseng, Angew. Chem. 2013, 52, 3379.

[44] F. Fachin, G. D. Chen, M. Toner, B. L. Wardle, J. Microelectromech. Syst. 2011, 20, 1428.

[45] H. J. Yoon, M. Kozminsky, S. Nagrath, ACS Nano 2014, 8, 1995. 
[46] N. Zhang, Y. Deng, Q. Tai, B. Cheng, L. Zhao, Q. Shen, R. He, L. Hong, W. Liu, S. Guo, K. Liu, H. R. Tseng, B. Xiong, X. Z. Zhao, Adv. Mater. 2012, 24, 2756.

[47] J. P. Gleghorn, E. D. Pratt, D. Denning, H. Liu, N. H. Bander, S. T. Tagawa, D. M. Nanus, P. A. Giannakakou, B. J. Kirby, Lab Chip 2010, 10, 27.

[48] G. Galletti, M. S. Sung, L. T. Vahdat, M. A. Shah, S. M. Santana, G. Altavilla, B. J. Kirby, P. Giannakakou, Lab Chip 2014, 14, 147.

[49] W. Sheng, T. Chen, R. Kamath, X. Xiong, W. Tan, Z. H. Fan, Anal. Chem. 2012, 84, 4199.

[50] L. Wong, W. Bateman, A. Morris, I. Fraser, Br. J. Surg. 1995, 82, 1333.

[51] K. Hoshino, Y. Y. Huang, N. Lane, M. Huebschman, J. W. Uhr, E. P. Frenkel, X. Zhang, Lab Chip 2011, 11, 3449.

[52] B. P. Casavant, R. Mosher, J. W. Warrick, L. J. Maccoux, S. M. Berry, J. T. Becker, V. Chen, J. M. Lang, D. G. McNeel, D. J. Beebe, Methods 2013, 64, 137.

[53] E. Ozkumur, A. M. Shah, J. C. Ciciliano, B. L. Emmink, D. T. Miyamoto, E. Brachtel, M. Yu, P. I. Chen, B. Morgan, J. Trautwein, A. Kimura, S. Sengupta, S. L. Stott, N. M. Karabacak, T. A. Barber, J. R. Walsh, K. Smith, P. S. Spuhler, J. P. Sullivan, R. J. Lee, D. T. Ting, X. Luo, A. T. Shaw, A. Bardia, L. V. Sequist, D. N. Louis, S. Maheswaran, R. Kapur, D. A. Haber, M. Toner, Sci. Transl. Med. 2013, 5, 179 ra47.

[54] Y. Wu, C. J. Deighan, B. L. Miller, P. Balasubramanian, M. B. Lustberg, M. Zborowski, J. J. Chalmers, Methods 2013, 64, 169.

[55] Z. Liu, W. Zhang, F. Huang, H. Feng, W. Shu, X. Xu, Y. Chen, Biosens. Bioelectron. 2013, 47, 113.

[56] V. Murlidhar, M. Zeinali, S. Grabauskiene, M. Ghannad-Rezaie, M. S. Wicha, D. M. Simeone, N. Ramnath, R. M. Reddy, S. Nagrath, Small 2014, 10, 4895.

[57] N. Saucedo-Zeni, S. Mewes, R. Niestroj, L. Gasiorowski, D. Murawa, P. Nowaczyk, T. Tomasi, E. Weber, G. Dworacki, N. G. Morgenthaler, H. Jansen, C. Propping, K. Sterzynska, W. Dyszkiewicz, M. Zabel, M. Kiechle, U. Reuning, M. Schmitt, K. Lucke, Int. J. Oncol. 2012, 41, 1241.

[58] I. Baccelli, A. Schneeweiss, S. Riethdorf, A. Stenzinger, A. Schillert, V. Vogel, C. Klein, M. Saini, T. Bauerle, M. Wallwiener, T. Holland-Letz, T. Hofner, M. Sprick, M. Scharpff, F. Marme, H. P. Sinn, K. Pantel, W. Weichert, A. Trumpp, Nat. Biotechnol. 2013, 31, 539.

[59] F. L. Carvalho, B. W. Simons, E. S. Antonarakis, Z. Rasheed, N. Douglas, D. Villegas, W. Matsui, D. M. Berman, Oncotarget 2013, 4, 413.

[60] H. W. Hou, M. E. Warkiani, B. L. Khoo, Z. R. Li, R. A. Soo, D. S. Tan, W. T. Lim, J. Han, A. A. Bhagat, C. T. Lim, Sci. Rep. 2013, 3, 1259.

[61] Z. Zhang, H. Shiratsuchi, J. Lin, G. Chen, R. M. Reddy, E. Azizi, S. Fouladdel, A. C. Chang, L. Lin, H. Jiang, M. Waghray, G. Luker, D. M. Simeone, M. S. Wicha, D. G. Beer, N. Ramnath, S. Nagrath, Oncotarget 2014, 5, 12383.

[62] F. I. Thege, T. B. Lannin, T. N. Saha, S. Tsai, M. L. Kochman, M. A. Hollingsworth, A. D. Rhim, B. J. Kirby, Lab Chip 2014, 14, 1775.

[63] N. Aceto, M. Toner, S. Maheswaran, D. A. Haber, Trends Cancer 2015, 1, 44.

[64] A. F. Sarioglu, N. Aceto, N. Kojic, M. C. Donaldson, M. Zeinali, B. Hamza, A. Engstrom, H. Zhu, T. K. Sundaresan, D. T. Miyamoto, X. Luo, A. Bardia, B. S. Wittner, S. Ramaswamy, T. Shioda, D. T. Ting, S. L. Stott, R. Kapur, S. Maheswaran, D. A. Haber, M. Toner, Nat. Methods 2015, 12, 685.

[65] N. Sethi, Y. Kang, Nat. Rev. Cancer 2011, 11, 735.

[66] L. J. Gay, B. Felding-Habermann, Nat. Rev. Cancer 2011, 11, 123.

[67] M. Labelle, S. Begum, R. O. Hynes, Cancer Cell 2011, 20, 576.

[68] M. S. Wicha, D. F. Hayes, J. Clinical Oncol. 2011, 29, 1508.
[69] A. M. Shah, M. Yu, Z. Nakamura, J. Ciciliano, M. Ulman, K. Kotz, S. L. Stott, S. Maheswaran, D. A. Haber, M. Toner, Anal. Chem. 2012, 84, 3682.

[70] N. Gerges, J. Rak, N. Jabado, Br. Med. Bull. 2010, 94, 49.

[71] S. McKenzie, L. Williams, Clinical Laboratory Hematology, Prentice Hall, Upper Saddle River, NJ, USA 2004.

[72] P. Li, Z. Mao, Z. Peng, L. Zhou, Y. Chen, P. H. Huang, C. I. Truica, J. J. Drabick, W. S. El-Deiry, M. Dao, S. Suresh, T. J. Huang, Proc. Nat. Acad. Sci. USA 2015, 112, 4970.

[73] X. Ding, Z. Peng, S. C. Lin, M. Geri, S. Li, P. Li, Y. Chen, M. Dao, S. Suresh, T. J. Huang, Proc. Nat. Acad. Sci. USA 2014, 111, 12992.

[74] V. P. Zharov, E. I. Galanzha, E. V. Shashkov, N. G. Khlebtsov, V. V. Tuchin, Opt. Lett. 2006, 31, 3623.

[75] K. G. Phillips, A. Kolatkar, K. J. Rees, R. Rigg, D. Marrinucci, M. Luttgen, K. Bethel, P. Kuhn, O. J. McCarty, Front Oncol. 2012, 2, 96 .

[76] C. Jin, S. M. McFaul, S. P. Duffy, X. Deng, P. Tavassoli, P. C. Black, H. Ma, Lab Chip 2014, 14, 32.

[77] I. Cima, C. Wen Yee, F. S. Iliescu, W. M. Phyo, K. H. Lim, C. Iliescu, M. H. Tan, Biomicrofluidics 2013, 7, 11810.

[78] G. Vona, A. Sabile, M. Louha, V. Sitruk, S. Romana, K. Schutze, F. Capron, D. Franco, M. Pazzagli, M. Vekemans, B. Lacour, C. Brechot, P. Paterlini-Brechot, Am. J. Pathol. 2000, 156, 57.

[79] J. M. Hou, M. Krebs, T. Ward, R. Sloane, L. Priest, A. Hughes, G. Clack, M. Ranson, F. Blackhall, C. Dive, Am. J. Pathol. 2011, $178,989$.

[80] V. De Giorgi, P. Pinzani, F. Salvianti, J. Panelos, M. Paglierani, A. Janowska, M. Grazzini, J. Wechsler, C. Orlando, M. Santucci, J. Invest. Dermatol. 2010, 130, 2440.

[81] I. Desitter, B. S. Guerrouahen, N. Benali-Furet, J. Wechsler, P. A. Janne, Y. Kuang, M. Yanagita, L. Wang, J. A. Berkowitz, R. J. Distel, Y. E. Cayre, Anticancer Res. 2011, 31, 427.

[82] S. Zheng, H. Lin, J. Q. Liu, M. Balic, R. Datar, R. J. Cote, Y. C. Tai, J. Chromatogr. A 2007, 1162, 154.

[83] H. K. Lin, S. Zheng, A. J. Williams, M. Balic, S. Groshen, H. I. Scher, M. Fleisher, W. Stadler, R. H. Datar, Y. C. Tai, R. J. Cote, Clin. Cancer Res. 2010, 16, 5011.

[84] S. Zheng, H. K. Lin, B. Lu, A. Williams, R. Datar, R. J. Cote, Y. C. Tai, Biomed. Microdevices 2011, 13, 203.

[85] M. Hosokawa, T. Hayata, Y. Fukuda, A. Arakaki, T. Yoshino, T. Tanaka, T. Matsunaga, Anal. Chem. 2010, 82, 6629.

[86] L. S. Lim, M. Hu, M. C. Huang, W. C. Cheong, A. T. Gan, X. L. Looi, S. M. Leong, E. S. Koay, M. H. Li, Lab Chip 2012, 12, 4388.

[87] S. J. Tan, R. L. Lakshmi, P. Chen, W. T. Lim, L. Yobas, C. T. Lim, Biosens. Bioelectron. 2010, 26, 1701.

[88] M. D. Zhou, S. Hao, A. J. Williams, R. A. Harouaka, B. Schrand, S. Rawal, Z. Ao, R. Brenneman, E. Gilboa, B. Lu, S. Wang, J. Zhu, R. Datar, R. Cote, Y. C. Tai, S. Y. Zheng, Sci. Rep. 2014, 4, 7392.

[89] D. Di Carlo, D. Irimia, R. G. Tompkins, M. Toner, Proc. Nat. Acad. Sci. USA 2007, 104, 18892.

[90] A. Russom, A. K. Gupta, S. Nagrath, D. Di Carlo, J. F. Edd, M. Toner, New J. Phys. 2009, 11, 75025.

[91] S. Choi, T. Ku, S. Song, C. Choi, J. K. Park, LabChip 2011, 11, 413.

[92] J. A. Davis, D. W. Inglis, K. J. Morton, D. A. Lawrence, L. R. Huang, S. Y. Chou, J. C. Sturm, R. H. Austin, Proc. Nat. Acad. Sci. USA 2006, 103, 14779.

[93] A. Lee, J. Park, M. Lim, V. Sunkara, S. Y. Kim, G. H. Kim, M. H. Kim, Y. K. Cho, Anal. Chem. 2014, 86, 11349.

[94] A. Eramo, F. Lotti, G. Sette, E. Pilozzi, M. Biffoni, A. Di Virgilio, C. Conticello, L. Ruco, C. Peschle, R. De Maria, Cell Death Differ. 2008, 15, 504.

[95] T. H. Kim, H. J. Yoon, P. Stella, S. Nagrath, Biomicrofluidics 2014, $8,064117$. 
www.MaterialsViews.com

[96] E. Sollier, D. E. Go, J. Che, D. R. Gossett, S. O’Byrne, W. M. Weaver, N. Kummer, M. Rettig, J. Goldman, N. Nickols, S. McCloskey, R. P. Kulkarni, D. Di Carlo, Lab Chip 2014, 14, 63.

[97] K. A. Hyun, K. Kwon, H. Han, S. I. Kim, H. I. Jung, Biosens. Bioelectron. 2013, 40, 206.

[98] M. E. Warkiani, G. Guan, K. B. Luan, W. C. Lee, A. A. Bhagat, P. K. Chaudhuri, D. S. Tan, W. T. Lim, S. C. Lee, P. C. Chen, C. T. Lim, J. Han, Lab Chip 2014, 14, 128.

[99] M. E. Warkiani, B. L. Khoo, D. S. Tan, A. A. Bhagat, W. T. Lim, Y. S. Yap, S. C. Lee, R. A. Soo, J. Han, C. T. Lim, Analyst 2014, $139,3245$.

[100] B. L. Khoo, M. E. Warkiani, D. S. Tan, A. A. Bhagat, D. Irwin, D. P. Lau, A. S. Lim, K. H. Lim, S. S. Krisna, W. T. Lim, Y. S. Yap, S. C. Lee, R. A. Soo, J. Han, C. T. Lim, Plos One 2014, 9, e99409.

[101] F. F. Becker, X. B. Wang, Y. Huang, R. Pethig, J. Vykoukal, P. R. Gascoyne, Proc. Nat. Acad. Sci. USA 1995, 92, 860.

[102] S. Shim, K. Stemke-Hale, A. M. Tsimberidou, J. Noshari, T. E. Anderson, P. R. Gascoyne, Biomicrofluidics 2013, 7, 11807.

[103] H. Choi, K. B. Kim, C. S. Jeon, I. Hwang, S. Lee, H. K. Kim, H. C. Kim, T. D. Chung, Lab Chip 2013, 13, 970.

[104] K. J. Cheung, V. Padmanaban, V. Silvestri, K. Schipper, J. D. Cohen, A. N. Fairchild, M. A. Gorin, J. E. Verdone, K. J. Pienta, J. S. Bader, A. J. Ewald, Proc. Nat. Acad. Sci. USA 2016, 113, E854.

[105] D. Marrinucci, K. Bethel, D. Lazar, J. Fisher, E. Huynh, P. Clark, R. Bruce, J. Nieva, P. Kuhn, J. Oncol. 2010, 2010, 861341.

[106] D. R. Gossett, W. M. Weaver, A. J. Mach, S. C. Hur, H. T. Tse, W. Lee, H. Amini, D. Di Carlo, Anal. Bioanal. Chem. 2010, 397, 3249.

[107] Z. T. Yu, K. M. Aw Yong, J. Fu, Small 2014, 10, 1687.

[108] Z. H. Fan, D. J. Beebe, Lab Chip 2014, 14, 12.

[109] H. J. Yoon, A. Shanker, Y. Wang, M. Kozminsky, Q. Jin, N. Palanisamy, M. L. Burness, E. Azizi, D. M. Simeone, M. S. Wicha, J. Kim, S. Nagrath, Adv. Mater. 2016, 28, 4891.

[110] C. L. Hodgkinson, C. J. Morrow, Y. Li, R. L. Metcalf, D. G. Rothwell, F. Trapani, R. Polanski, D. J. Burt, K. L. Simpson, K. Morris, S. D. Pepper, D. Nonaka, A. Greystoke, P. Kelly, B. Bola, M. G. Krebs, J. Antonello, M. Ayub, S. Faulkner, L. Priest, L. Carter, C. Tate, C. J. Miller, F. Blackhall, G. Brady, C. Dive, Nat. Med. 2014, 20, 897.

[111] M. Yu, A. Bardia, N. Aceto, F. Bersani, M. W. Madden, M. C. Donaldson, R. Desai, H. Zhu, V. Comaills, Z. Zheng,
B. S. Wittner, P. Stojanov, E. Brachtel, D. Sgroi, R. Kapur, T. Shioda, D. T. Ting, S. Ramaswamy, G. Getz, A. J. lafrate, C. Benes, M. Toner, S. Maheswaran, D. A. Haber, Science 2014, 345, 216.

[112] L. Cayrefourcq, T. Mazard, S. Joosse, J. Solassol, J. Ramos, E. Assenat, U. Schumacher, V. Costes, T. Maudelonde, K. Pantel, C. Alix-Panabieres, Cancer Res. 2015, 75, 892.

[113] C. Alix-Panabieres, K. Pantel, Nat. Rev. Cancer 2014, 14, 623.

[114] S. A. Joosse, T. M. Gorges, K. Pantel, EMBO Mol. Med. 2015, $7,1$.

[115] Z. Zhang, N. Ramnath, S. Nagrath, Front Oncol. 2015, 5, 209.

[116] J. S. de Bono, H. I. Scher, R. B. Montgomery, C. Parker, M. C. Miller, H. Tissing, G. V. Doyle, L. W. Terstappen, K. J. Pienta, D. Raghavan, Clin. Cancer Res. 2008, 14, 6302 .

[117] D. A. Smirnov, D. R. Zweitzig, B. W. Foulk, M. C. Miller, G. V. Doyle, K. J. Pienta, N. J. Meropol, L. M. Weiner, S. J. Cohen, J. G. Moreno, M. C. Connelly, L. W. Terstappen, S. M. O'Hara, Cancer Res. 2005, 65, 4993.

[118] M. A. Leversha, J. Han, Z. Asgari, D. C. Danila, O. Lin, R. Gonzalez-Espinoza, A. Anand, H. Lilja, G. Heller, M. Fleisher, H. I. Scher, Clinical Cancer Res. 2009, 15, 2091.

[119] G. Attard, J. F. Swennenhuis, D. Olmos, A. H. Reid, E. Vickers, R. A'Hern, R. Levink, F. Coumans, J. Moreira, R. Riisnaes, N. B. Oommen, G. Hawche, C. Jameson, E. Thompson, R. Sipkema, C. P. Carden, C. Parker, D. Dearnaley, S. B. Kaye, C. S. Cooper, A. Molina, M. E. Cox, L. W. Terstappen, J. S. de Bono, Cancer Res. 2009, 69, 2912.

[120] M. Chimonidou, A. Strati, N. Malamos, V. Georgoulias, E. S. Lianidou, Clin. Chem. 2013, 59, 270.

[121] M. Chimonidou, G. Kallergi, V. Georgoulias, D. R. Welch, E. S. Lianidou, Mol. Cancer Res. 2013, 11, 1248.

[122] N. Malara, M. L. Coluccio, T. Limongi, M. Asande, V. Trunzo, G. Cojoc, C. Raso, P. Candeloro, G. Perozziello, R. Raimondo, S. De Vitis, L. Roveda, M. Renne, U. Prati, V. Mollace, E. Di Fabrizio, Small 2014, 10, 4324.

[123] R. M. Jack, M. M. G. Grafton, D. Rodrigues, M. D. Giraldez, C. Griffith, R. Cieslak, M. Zeinali, C. Kumar Sinha, E. Azizi, M. Wicha, M. Tewari, D. M. Simeone, S. Nagrath, Adv. Sci. 2016, DOI: $10.1002 /$ advs.201600063.

Received: April 22, 2016 Revised: May 30, 2016 Published online: July 20, 2016 